\title{
Analysis of Effective Strategies for the Integration of Financial Accounting and Management Accounting
}

\author{
Ma Meng \\ Accounting College of Shaanxi Vocational and Technical College of Finance and Economics, \\ Xianyang, Shaanxi, 712000
}

Keywords: financial accounting; management accounting; integration; effective strategies

\begin{abstract}
Accounting is an important part of enterprise development, which is updated with the development of the social era. Facing the increasingly fierce market economy, the traditional accounting model is no longer applicable to the new economic environment. It is reasonable to deeply integrate financial accounting and management accounting in order to constantly maintain the stability of enterprises and promote the development of enterprises. Based on the feasibility analysis of the integration of financial accounting and management accounting, this paper explores the effective strategies of the integration of financial accounting and management accounting to promote social and economic development.
\end{abstract}

\section{The Concept of Financial Accounting and Management Accounting}

Financial accounting is a branch of enterprise accounting. It mainly refers to the comprehensive and systematic supervision and accounting of completed capital activities in the process of production and operation, so as to provide economic information for business decision-making, investors and creditors related to the economic interests of enterprises, better serve business management and promote the economic efficiency of enterprises. Management accounting is also an enterprise association. The branch of accounting, also known as "Analytical Reporting Accounting", mainly refers to the process of enterprise production and operation, in which enterprise management departments using a series of accounting management methods to collect, collate, analyze and record various economic information, and on this basis to predict and formulate plans to control economic activities, so as to improve the quality of enterprise internal management and promote the economic efficiency of enterprises.

\section{The Feasibility Analysis of the Integration of Financial Accounting and Management Accounting}

In order to maintain the internal stability of enterprises and promote the rapid development of enterprises, financial accounting and management accounting should be deeply integrated. Why can they be integrated? Its feasibility has the following aspects: Firstly, they have the same status and functions, because in the daily operation and management activities of enterprises, financial accounting and management accounting are both important components, but their focus is different: 
financial accounting mainly manages the accounts of enterprises, records and plans; management accounting mainly collects and processes data and supervision. However, both of them are responsible for the determination, estimation and prediction of enterprise operation data and actual transaction situation in the process of enterprise operation. Secondly, the objectives of financial accounting and management accounting are the same. Although they have different emphases, they all have one purpose, that is, to safeguard the rights and interests of enterprises and improve the level of economic development and management of enterprises. Thirdly, financial accountants and managerial accountants can communicate with each other and make progress together in order to better plan and pave the way for the development of enterprises.

\section{Specific Strategies for Effective Integration of Financial Accounting and Management Accounting}

\subsection{Establish a Correct Sense of Integration}

In order to achieve the effective integration of financial accounting and management accounting, it is necessary to establish a correct sense of integration for the relevant personnel of enterprises. Only by fully recognizing the importance of accounting for enterprise development, strengthening the integration between financial accounting and management accounting, and giving full play to their functions, can the development of enterprises be promoted together.

\subsection{Training Professional Compound Accountants}

The professionalism of accounting staff directly affects the efficient operation of enterprise accounting management. Therefore, in the process of enterprise development, it is necessary to train professional and compound accountants' ability, that is, to train staff with necessary training and learning so as to make their professional level meet the needs of the times.

\subsection{Introducing advanced Information Technology to Improve the Accounting Efficiency}

In order to improve the efficiency of accounting work, enterprises should introduce advanced information technology while effectively integrating financial accounting and management. For example, in the actual process of accounting work, we can use information technology to convert specific data into electronic information, and then classify, analyze and estimate, in order to ensure the accuracy and rationality of the budget and improve the quality of enterprise decision-making.

\section{Conclusion}

The integration and development of financial accounting and management accounting is the inevitable trend of management system reform in the process of enterprise transformation and upgrading in the new era. On the basis of the feasibility analysis of the integration of financial accounting and management accounting, we adopt such strategies as establishing correct integration consciousness, training professional compound staff and introducing advanced information technology to promote the integration of financial accounting and management accounting, and then improve the management and income level of enterprises.

\section{References}

[1] Dong Xinyu. A Preliminary Study on the Integration of Management Accounting and Financial Accounting [J]. China Commerce, 2018 (34): 137-138. 
[2] Cui Jin. Analysis of effective strategies for the integration of financial accounting and management accounting [J]. Modern Marketing (Operational Edition), 2019 (01): 164.

[3] Dong Qi-meng. The organic integration and innovative development of financial accounting and management accounting [J].Southern Agricultural Machinery, 2018,49(17): 108. 